\section{Health, childlessness and poverty in Latin American countries}

\author{
Salud, no tener hijos y pobreza en países \\ latinoamericanos
}

Saúde, mulheres sem filhos e pobreza em países da América Latina
Ruben Castro 1

Juan Tapia 1

\begin{abstract}
Recent literature proposes that poverty could lead women to remain childless, thus attenuating or reverting higher fertility typically observed among women of lower schooling level. We explore the role of health in this approach: does health have a distinctive detrimental effect on fertility among women of lower schooling levels? To that end, we compute the gap in the definite childlessness rate by self-reported disability status across schooling levels. Due to the scarcity of survey data from definite childless women, in addition to the small sample sizes, we use census samples. Focusing on women between 40-50 years old and using 23 census samples from Latin America countries (2000-2011), we found that only in the group with lower schooling level there is a clear gap in the definite childlessness rate by self-reported disability status. From our descriptive analysis we conclude that health could indeed play an influential role in the childless by poverty approach.
\end{abstract}

Fertility; Education; Poverty

\section{Correspondence}

R. Castro

Universidad Técnica Federico Santa María.

Av. España \# 1680, Valparaíso / V Región - 8370056, Chile.

ruben.castrol@usm.cl

1 Universidad Técnica Federico Santa María, Valparaiso, Chile. 


\section{Introduction}

Female health, fertility and socioeconomic position are intrinsically linked. Those issues are closely related to fundamental goals of well-being and gender equality 1 , and the intersection between them is a central topic in the social sciences.

An emerging topic in fertility dynamics is childlessness. Although childlessness has never been uncommon (there is evidence, for example, of cases from pre-industrial England 2 and France 3), childlessness has grown in many countries and fertility rates have decreased to low or even very low levels 4,5 .

Meanwhile, more studies are drawing attention to the need to better understand the phenomena of childlessness 6,7,8,9. In the words of Tomas Frejka 10 (p. 176), a key author in this field, "the mechanisms that shaped the facts [childlessness] have not been thoroughly deciphered".

The available literature provides evidence of the influence of economic and social conditions as well as cultural norms on the path to childlessness; those are probably among the most influential determinants for this phenomenon ${ }^{10}$. There is also an ongoing discussion about the different paths to childlessness, mostly focused on childless women without addressing the childlessness rate. Besides the mutual causation between socioeconomics, demography and health issues, one regularity in the results from individual-level analysis is the well-known association between higher schooling levels and higher childlessness.

The literature about education and childlessness, however, has focused on highly educated women when compared to their counterparts, leaving the childless and disadvantaged women relatively out of the main picture. The dynamics of childlessness among such women are often not in line with common wisdom: their childless rate is usually higher than that of women with secondary education, therefore breaking the expected association between childlessness and education. Indeed, in a demographic study of cohorts with completed fertility, the results for nine out of 18 European countries showed higher childlessness rates among women with lower schooling level 11. A recent book on childlessness in developed countries tells mostly the same story; be it in France 12, Germany 13, Finland 14 and Sweden 15. As we show in our study, the same is true in several Latin American countries.

Thus far there is no clear explanation for the higher childlessness rate among women with lower schooling levels. Only a few papers discuss the issue, mentioning that difficulties in civil union formation were a central factor behind the higher childlessness rate of women with lower schooling level in Finland 14 and France 12. We argue that health issues could be another reason. The available literature focuses on infecundity as an obvious explanation to involuntary childlessness, but infecundity probably explains little of this phenomenon 16 (as, for example, is the case in Europe 11) thus allowing for more diverse roles for health. One study 14 already drew attention to the access to health services of childless women with lower schooling level, as well as infertility treatments, and counselling. Additionally, a study of childlessness in Poland 8 found that childless-and-disadvantaged women report health issues as a primary factor on their lives. Moreover, higher childlessness among black women in the United States during the 20th century has been linked, at least in part, to socioeconomic disadvantages 11.

One approach to understand how the intersection of health and poverty is determinant for childlessness is the idea of "childless by poverty", i.e., the idea that women in poverty might be forced to remain childless. This approach, developed in Baudin et al. 17,18, is based on the theory of capabilities, where poverty is seen as a matter of means and freedom 19 . In this model, women need to consume a minimum level of resources in order to become mothers. The causation in this argument, therefore, goes from poverty to childlessness. Baudin et al. 17,18 briefly propose that health issues could be the main mediating factors linking childlessness to poverty, as health issues push poorer women below the minimum level of consumption. For the United States, a Baudin et al. study 17 found a U-shape association between childlessness and education, and thus concluded that poverty explains one extreme while opportunity costs the other. Then, focusing on 36 non-developed countries, another Baudin et al. study 18 used a behavioral model including the variables education, time cost, preferences, non-labor income, bargaining, minimum consumption, natural sterility, mortality rates and assortative matching, and found that in the poorest countries, childlessness is mostly driven by 
poverty. Baudin et al. 17,18 argue that a substantial proportion of childlessness in the lower schooling group can be attributed to poverty.

Health issues could be part of the explanation for the higher-than-expected childlessness among women with lower schooling level. To add quantitative evidence on the role of health, we use census data to compute the childlessness rate by schooling level and disability groups. Disability is one of the most important measures of health and is central in various summary measures of well-being (such as the DALYs, i.e., disability-adjusted life years). Nearly all available scientific literature on childlessness by schooling level is focused on developed countries, while our study is focused on Latin American countries. We found that in most countries, and most regions within a country, the childlessness rate of women with disabilities is slightly higher than that of able-bodied women; except for the group with lower schooling levels, in which women with disabilities show a considerably higher childlessness rate. Our findings do not prove a causal relation between health, poverty and childlessness, but they do uncover an empirical regularity that is visible across most countries in our database and most regions within those countries.

\section{Data and methods}

Our study focuses on definite childlessness. Many economic studies about fertility focus on the first child, or the second, and so on. The first child marks the transition from temporary childlessness to motherhood, but the concept of childlessness is much more related to the idea of definite rather than temporary childlessness 20 , that is, the proportion of women past their reproductive age that did not have any live births. Studies on childlessness trends 21,22, longitudinal studies of pathways into childlessness 9,23,24 and the impact of employment on childlessness 15,25,26,27, have a natural focus on definite childlessness. Naturally, the literature on the consequences of childlessness for older individuals, and its long-term implications for demographic changes and human reproduction, depends crucially on definite rather than temporary fertility.

\section{Data}

The sample sizes available for the study of definite childlessness are very low: the subsample of childless women with low schooling level in the 40 to 50-year-old range (upper boundary set in order to avoid the additional influence of pension dynamics on the analysis) can be a minimal proportion of the overall sample. Moreover, most socioeconomic surveys lack a question on total fertility; in fact, several studies use the absence of a co-residential own-children as an indicator of childlessness, but this is probably not accurate in the 40 and over age range 20,28, especially in the contexts of high migration 29. There is not much evidence on the association between definite childlessness and different socioeconomic measures.

We used census samples for this study. First, childless women in the 40-50 years range are relatively scarce; survey data about uncommon groups are especially sensitive to both sampling and nonsampling errors. Second, censuses are among the few sources that include the question of "how many children have you ever had?". Lastly, there is a wide set of microdata from census samples available at the IPUMS project website (https://international.ipums.org/international/), carefully organized and standardized (The Integrated Public Use Microdata Series project is a collaboration of the University of Minnesota/USA, National Statistical Offices, international data archives, and other international organizations). Africa and Latin America are the two most common regions in the data, but we focus on Latin American countries only because in Africa the group with lower schooling level is too prevalent and therefore it is probably not a good marker for relative poverty.

The census samples in our study are: Brazil 2000 and 2010; Chile 2002; Colombia 2005; Costa Rica 2000 and 2011; Dominican Republic 2002 and 2010; Ecuador 2001 and 2010; El Salvador 2007; Haiti 2003; Jamaica 2001; Mexico 2000 and 2010; Panama 2000 and 2010; Paraguay 2002; Trinidad and Tobago 2000 and 2011; Uruguay 2006 and 2011; and Venezuela 2001. 


\section{Education and health measures}

The variable selected for education is the maximum level of education attained, called edattain in the IPUMS samples. This variable is harmonized by the IPUMS team, who explain that edattain is an attempt to merge samples that provide either degrees, actual years of schooling, and those that have some of both into a single, roughly comparable variable. The variable is categorized by: Less than primary completed, Primary completed, Secondary completed, and Tertiary completed.

We used a dichotomous indicator of self-reported disability as the health measure; this is the only personal health variable that is widely available in the census samples. However, measurements of prevalence of disability in an internationally comparable way is still a developing goal 30 of the World Report on Disability 31. Nevertheless, there is some consensus in the use of functionality questions regarding core activities 32 , which are the kind of questions included in our census samples. The variable Disabled in the IPUMS samples indicates whether the person reported at least one disability of any kind. In the census samples where the disability variables provide several degrees of difficulty, disabled applies the threshold of "significant" or "severe" difficulty to define disability. In the case of the Brazil 2000 census, for example, a person is coded "disabled" if they reported the loss of use of a limb, hand, or foot; had a mental disability; or if they reported a "significant permanent difficulty" in seeing, hearing, or walking. In the 2010 census, a person is coded "disabled" if they reported significant difficulty seeing, hearing or walking or if they reported having a permanent mental or intellectual disability. Both censuses, nevertheless, are fairly coherent regarding age-specific disability rates 33 .

It is important to mention that the definition of disability changes to some degree across samples. Even though our focus is on the differences between disabled and able-bodied women rather than on the level of disability, it is necessary to address the influence of international heterogeneity on the censuses' disability questions. Two analyses were conducted: First, we explored whether samples with comparatively low or high prevalence of disability show different results, as the prevalence of disability itself may capture some of the heterogeneity in the definition, and found no substantial difference in the results. Second, we checked whether our results for the entire country were equally visible for each region of the country, as in this case the disability measure is constant across regions. We found that subnational figures mirror the national ones.

\section{Methods}

In our descriptive study, we computed the childless rate among disabled and able-bodied women across schooling levels. We initially conducted the analysis at the national level, and then at a sub national level; this was done using the "geographical region" variable, available in 18 out of 23 census samples in our study.

We also used the IPUMS microdata to perform a linear regression analysis of childlessness (the dependent variable) on the interaction between education and disability (the key dependent variable) plus education, disability, sample, and dummies.

\section{Results}

The Supplementary Material (http://cadernos.ensp.fiocruz.br/static//arquivo/suppl-e00248919_ 6031.pdf) contains the relevant data for the following analysis and shows the simple means across samples by educational group.

Table 1 shows that, in line with the results from European countries discussed above, in Latin American countries the childless rate in the lower schooling group is slightly higher than the rate in the average schooling group. Out of the 23 census samples in our study, only five samples did not show higher childlessness rates for the lower schooling group as compared to the average schooling group (Brazil 2000, Ecuador 2001, Haiti 2003, Mexico 2000 and Paraguay 2002). The disability rates on Table 1, on the other hand, follow the well-known health-to-education gradient. 
Table 1

Mean * disability and childless rate by education level.

\begin{tabular}{lccc}
\hline Education group & Disability rate (\%) & Childless rate (\%) & Proportion of women (\%) ** \\
\hline Low & 8.5 & 7.4 & 28.7 \\
Average & 5.4 & 6.4 & 37.2 \\
High & 3.9 & 11.6 & 21.5 \\
Very high & 3.4 & 15.6 & 12.2 \\
\hline
\end{tabular}

Source: prepared by the authors.

Note: includes women in the 40-50-year-old range in 23 IPUMS census samples from Latin America.

* Mean across census samples;

** Due to the mean calculation, this does not add up to $100 \%$.

Next, we computed the childlessness rate for each sample by self-reported disability status and schooling level. We also computed the proportion of women that belonged to each schooling level, as lower schooling level might not easily be linked to poverty when it comprises a large proportion of women; Table 1 shows that the average proportion of women in the lower schooling level is $28.7 \%$, but this masks a high heterogeneity in this proportion. Figure 1 shows the results.

Each point in Figure 1 represents the childlessness rate of a given schooling and disability group for each sample. For example, the sample from the 2005 Colombian census (labeled "C2005" in Figure 1) shows a gap of about $10 \%$ in the lower schooling group, moving to a gap of about $1 \%$ in the higher schooling group.

Figure 1 shows that the lowest childlessness rates are found in the average schooling group. Figure 1 also shows that the childless gap between disabled and able-bodied women in the 40-50 age range is much clearer in the lower schooling group, especially if this group comprises $30 \%$ or less of the population. As such, the childlessness-health association appears stronger in the lower schooling group.

At the aggregated level, the childlessness rate is very similar between disabled and able-bodied women, except in the lower schooling group, especially when such a group comprises a small percentage of the population (and thus lower schooling is close to a measure of poverty). We then conducted a regression analysis.

Results in Table 2 show that for women with lower schooling level, the childlessness rate is 19\% higher among disabled women. For women with average or high schooling levels, that gap decreases to $5 \%$ (i.e., $19 \%$ minus $14 \%$ ). For women with very high schooling level, it decreases further to $3 \%$ (i.e., $19 \%$ minus 16\%). Controlling for the share of women in each level of education did not significantly alter the results. The regression analysis, then, confirms the results from Figure 1.

As census disability measures are not easily comparable across countries, we then focus on the regions within a country. One advantage of using census samples is that the same definition of disability is used across the whole country. We then separately analyzed each country in our sample. Figure 2 shows the results for the Brazil 2010 census.

In general, the childlessness rates across regions in the Brazil 2010 census are higher for women with higher schooling levels; however, the same pattern is not true for the group of women with lower schooling levels. From there, we confirm our results: the childlessness gap between disabled and ablebodied women in the 40-50 age range is much clearer in the lower schooling group. Among the 18 census samples in our study that include information on the geographic region of the respondent, four show unclear results while 14 (including Brazil 2010) show the same framework as Figure 1. 


\section{Figure 1}

Census samples: childless rate by disability status and education.

1a) Low

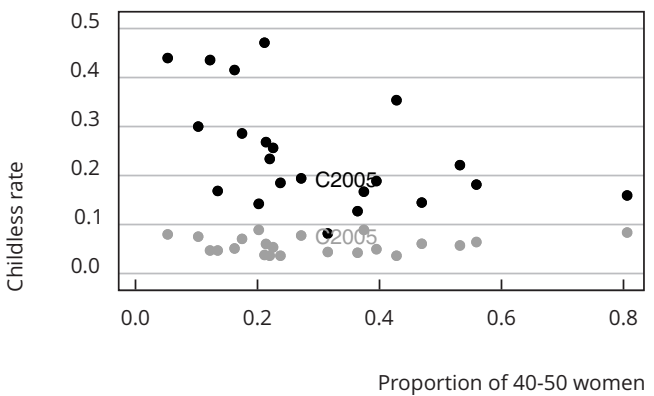

1c) Mid high

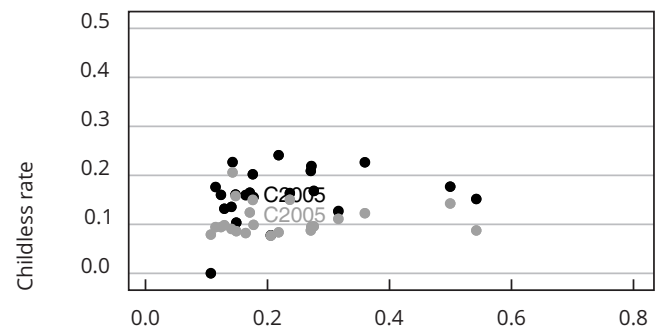

Proportion of 40-50 women 1b) Middle

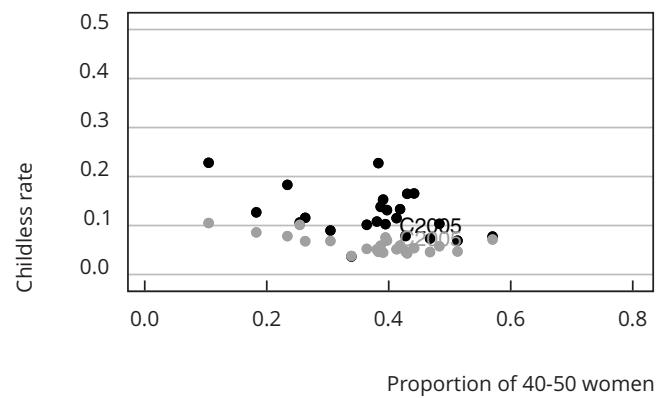

1d) High

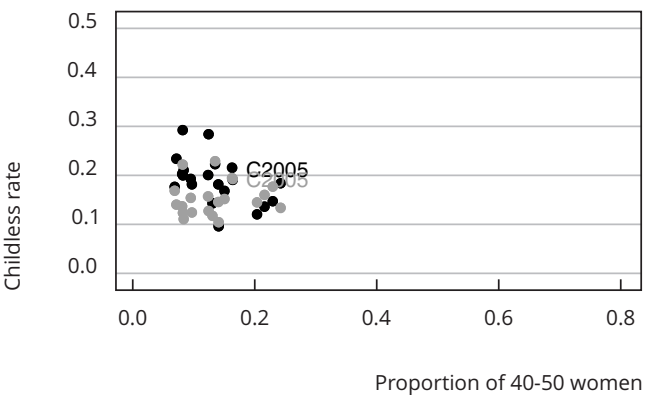

Source: prepared by the authors

Note: includes women in the 40-50-year-old range in 23 IPUMS census samples from Latin America, including Brazil 2000, Brazil 2010, Chile 2002,

Colombia 2005, Costa Rica 2000, Costa Rica 2011, Dominican Republic 2002, Dominican Republic 2010, Ecuador 2001, Ecuador 2010, El Salvador 2007, Haiti 2003, Jamaica 2001, México 2000, México 2010, Panamá 2000, Panamá 2010, Paraguay 2002, Trinidad and Tobago 2000, Trinidad and Tobago 2011, Uruguay 2006, Uruguay 2011 and Venezuela 2001. “C2005” stands for the sample from the 2005 Colombian census.

Table 2

Regression analysis on grouped data. Dependent variable: childless rate.

\begin{tabular}{|c|c|c|}
\hline Independent variable & Coefficient & p-value \\
\hline Disabled \& low education & Omitted & \\
\hline Disabled \& middle education & -0.14 & 0.00 \\
\hline Disabled \& high education & -0.14 & 0.00 \\
\hline Disabled \& very high education & -0.16 & 0.00 \\
\hline Disabled & 0.19 & 0.00 \\
\hline Low education & Omitted & \\
\hline Middle education & 0.00 & 0.63 \\
\hline High education & 0.06 & 0.00 \\
\hline Very high education & 0.10 & 0.00 \\
\hline Year, country dummies & Yes & \\
\hline Observations * & 184 & \\
\hline R-square & 0.65 & \\
\hline
\end{tabular}

Source: prepared by the authors.

Note: includes women in the 40-50-year-old range in 23 IPUMS census samples from Latin America.

* Each sample-disability status-education level is an observation. 


\section{Figure 2}

Regions in the Brazil 2010 census: childless rate by disability status and education.

2a) Low

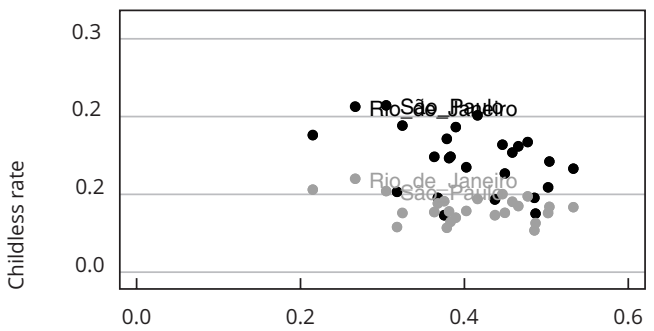

Proportion of 40-50 women

2c) Mid high

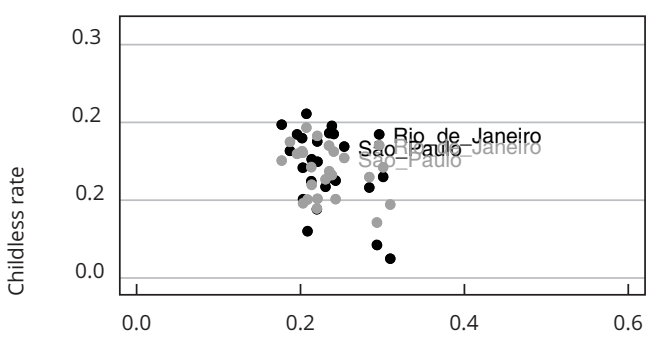

Proportion of 40-50 women 2b) Middle

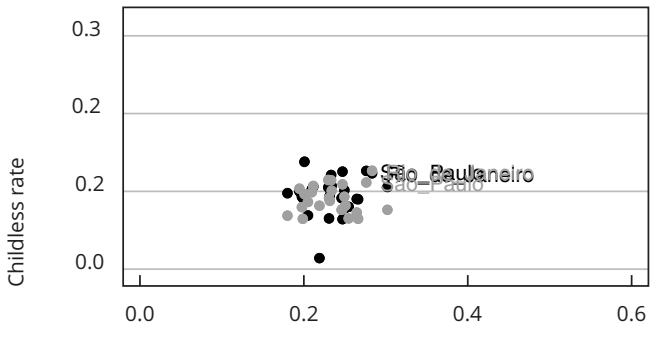

Proportion of 40-50 women

2d) High

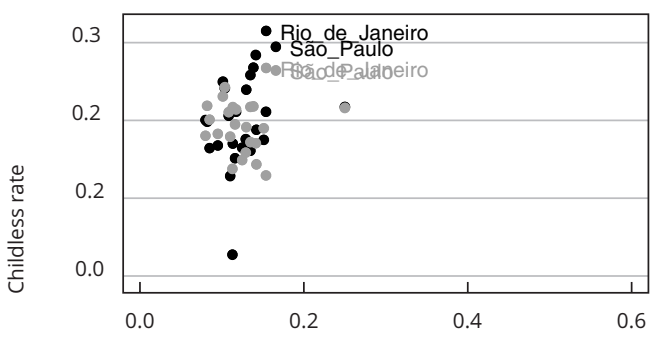

Proportion of 40-50 women
Disabled

Not disabled

Source: prepared by the authors.

Note: includes women in the 40-50-year-old range in 23 IPUMS census samples from Brazil, including Rondônia, Acre, Amazonas, Roraima, Pará, Amapá, Maranhão, Piauí, Ceará, Rio Grande do Norte, Paraíba, Pernambuco, Alagoas, Sergipe, Bahia, Minas Gerais, Espírito Santo, Rio de Janeiro, São Paulo, Paraná, Santa Catarina, Rio Grande do Sul, Mato Grosso do Sul, Goiás, and Federal District.

\section{Discussion}

There is a well-known association between higher schooling levels and higher childlessness, due to many economic and cultural reasons 10 , as well as other factors like longevity 34,35 .

Because higher schooling is so clearly associated with higher childlessness, we would expect low schooling to be associated with lower childlessness. However, as we discussed from the available literature regarding developed countries, as well as from our analysis of developing countries, lower schooling is commonly associated with higher childlessness.

There is no clear explanation for this finding. The literature on the so-called "voluntary" childlessness covers a wide range of dynamics, from the absolutely conscious and determined childlessness, to the situation of over-postponing and not finding suitable partners 5,36,37,38. This however does not explain why many women with lower schooling, mostly without careers, are also not having children. Neither the choice perspective, nor the preferences theory 39 offer a simple explanation. One possible hypothesis, from two mainly descriptive studies, is that union formation is lower in women with lower schooling level 12,14. Another possible explanation is "childless by poverty" 17,18, where poverty somehow forces women into not having children, with health issues probably representing the main link between poverty and childlessness 17,18. Indeed, we find that in most countries, and most regions within a country, the childlessness rate of disabled women is similar to that of able-bodied women, except for the group with lower schooling level. 
Further longitudinal analyses are necessary to explore the causal dynamics behind the healthpoverty-fertility association. In this study, we argue that health is one key variable behind the high childlessness rate observed among women with lower schooling levels; further research could explore the causal relations. In general, the interrelation of health, fertility and poverty is complex and heterogeneous 40,41 , and the mutual causation calls for a comprehensive conceptual approach 8,9,42. For example, although no clear causal links from childlessness to health among reproductive-age women are found in the literature, it is possible that childlessness might cause poverty and thus poor health. Childlessness in some social contexts can have social and psychological consequences, especially in developing countries 43,44; one may conclude that these social consequences could lead to poverty. Lastly, childlessness can have direct economic consequences in some poor areas ${ }^{40}$, even in developed countries like the United States; several studies argue that tax reliefs for less affluent mothers can cause relative poverty among less affluent childless women.

A limitation of our study is the international comparability of the censuses' self-reported disability measure. However, we explored whether samples with comparatively low or high prevalence of disability produce different results and found no substantial difference. Furthermore, we verified that our results were equally visible across regions within a country. Likewise, if women with lower schooling levels were more likely to overstate their self-reported disability, that would attenuate the childlessness gap between disabled and able-bodied women in that group; as such, this would attenuate our results rather than reinforce them.

\section{Contributors}

All the formulation of the data analysis, the analysis of results and the discussion was done by the two authors together. The writing of the manuscript was done by R. Castro, while revision was done by J. Tapia.

\section{Additional informations}

ORCID: Ruben Castro (0000-0002-7289-9081); Juan Tapia (0000-0001-7206-946X).

\section{References}

1. Brewster K, Rindfuss R. Fertility and women's employment in industrialized nations. Annu Rev Sociol 2000; 26:271-96.

2. de la Croix D, Schneider EB, Weisdorf J. Childlessness, celibacy and net fertility in pre-industrial England: the middle-class evolutionary advantage. J Econ Growth (Boston) 2019; 24:223-56.

3. de la Croix D, Brée S. Key forces behind the decline of fertility: lessons from childlessness in Rouen before the industrial revolution. Cliometrica 2019; 13:25-54.

4. Bongaarts J. Completing the fertility transition in the developing world: the role of educational differences and fertility preferences. Popul Stud (Camb) 2003; 57:321-35.

5. Sobotka T. Childlessness in Europe: reconstructing long-term trends among women born in 1900-1972. In: Kreyenfeld M, Konietzka D, editors. Childlessness in Europe: contexts, causes, and consequences. Cham: Springer; 2017. p. 17-53. (Demographic Research Monographs). 
6. Dykstra P, Hagestad GO. Roads less taken developing a nuanced view of older adults without children. J Fam Issues 2007; 28:1275-310.

7. Gobbi P. A model of voluntary childlessness. J Popul Econ 2013; 26:963-82.

8. Mynarska M, Matysiak A, Rybińska A, Tocchioni V, Vignoli D. Diverse paths into childlessness over the life course. Adv Life Course Res $2015 ; 25: 35-48$

9. Tanturri M, Mills M, Rotkirch A, Sobotka T, Takács J, Miettinen A, et al. State-of-the-art report: childlessness in Europe. Families and Society Working Paper Series 2015; (32). http:// www.familiesandsocieties.eu/wp-content/up loads/2015/03/WP32TanturriEtAl2015.pdf.

10. Frejka T. Childlessness in the United States. In: Kreyenfeld M, Konietzka D, editors. Childlessness in Europe: contexts, causes, and consequences. Cham: Springer; 2017. p. 159-79. (Demographic Research Monographs).

11. Miettinen A, Rotkirch A, Szalma I, Donno A, Tanturri M. Increasing childlessness in Europe: time trends and country differences. Families and Societies Working Paper Series 2014; (33). http://www.familiesandsocieties. eu/wp-content/uploads/2015/03/WP33Miet tinenEtAl2015.pdf.

12. Köppen K, Mazuy M, Toulemon L. Childlessness in France. In: Kreyenfeld M, Konietzka D, editors. Childlessness in Europe: contexts, causes, and consequences. Cham: Springer; 2017. p. 77-95. (Demographic Research Monographs).

13. Kreyenfeld M, Konietzka D. Childlessness in East and West Germany: long-term trends and social disparities. In: Kreyenfeld M, Konietzka D, editors. Childlessness in Europe: contexts, causes, and consequences. Cham: Springer; 2017. p. 97-114. (Demographic Research Monographs).

14. Rotkirch A, Miettinen A. Childlessness in Finland. In: Kreyenfeld M, Konietzka D, editors. Childlessness in Europe: contexts, causes, and consequences. Cham: Springer; 2017. p. 13958. (Demographic Research Monographs).

15. Neyer G, Hoem JM, Andersson G. Education and childlessness: the influence of educational field and educational level on childlessness among Swedish and Austrian women. In: Kreyenfeld M, Konietzka D, editors. Childlessness in Europe: contexts, causes, and consequences. Cham: Springer; 2017. p. 183-207. (Demographic Research Monographs).

16. Mascarenhas MN, Flaxman SR, Boerma T, Vanderpoel S, Stevens GA. National, regional, and global trends in infertility prevalence since 1990: a systematic analysis of 277 health surveys. PLoS Med 2012; 9:e1001356.

17. Baudin T, de la Croix D, Gobbi PE. Fertility and childlessness in the US. Am Econ Rev 2015; 105:1852-82.

18. Baudin T, de la Croix D, Gobbi PE. Endogenous childlessness and stages of development. Brussels: Universite Libre de Bruxelles; 2018. (Working Papers ECARES 2018-04).
19. Sen A. Capability and well-being. In: Nussbaum M, Sen A, editors. The quality of life. Oxford: Clarendon Press; 1993. p. 270-94.

20. Kendig H, Dykstra PA, van Gaalen RI, Melkas T. Health of aging parents and childless individuals. J Fam Issues 2007; 28:1457-86.

21. Kravdal $\varnothing$, Rindfuss RR. Changing relationships between education and fertility: a study of women and men born 1940 to 1964. Am Sociol Rev 2008; 73:854-73.

22. Isen A, Stevenson B. Women's education and family behavior: trends in marriage, divorce and fertility. Cambridge: National Bureau of Economic Research; 2010. (NBER Working Paper, 15725).

23. Blackstone A, Stewart MD. Choosing to be childfree: research on the decision not to parent. Sociology Compass 2012; 6:718-27.

24. Poston D, Cruz CE. Voluntary, involuntary and temporary childlessness in the United States. Revue Quetelet/Quetelet Journal 2016; 4:73-99.

25. Hoem JM, Neyer G. Education and childlessness: the relationship between educational field, educational level, and childlessness among Swedish women born in 1955-59. Demographic Research 2006; 14:331-80.

26. Bagavos C. Education and childlessness: the relationship between educational field, educational level, employment and childlessness among Greek women born in 1955-1959. Vienna Yearbook of Population Research 2010; 8:51-75.

27. Steele EJ, Giles LC, Davies MJ, Moore VM. Is precarious employment associated with women remaining childless until age 35 years? Results from an Australian birth cohort study. Hum Reprod 2014; 29:155-60.

28. Dykstra P, Wagner M. Pathways to childlessness and late-life outcomes. J Fam Issues 2007; 28:1487-517.

29. Dorrit P, van der Stoep G. Co-resident and absent mothers: motherhood and labour force participation in South Africa. Munich: University Library of Munich; 2008. (MPRA Paper, 52907).

30. McDermott S, Turk MA. The myth and reality of disability prevalence: measuring disability for research and service. Disabil Health J 2011; 4:1-5.

31. World Health Organization. World report on disability 2011. Geneva: World Health Organization; 2011.

32. Mont D. Measuring disability prevalence. Washington DC: World Bank; 2007.

33. Lenzi MB. Os dados sobre deficiência nos censos demográficos brasileiro. In: Anais do XVIII Encontro Nacional de Estudos Populacionais. http://www.abep.org.br/publicacoes/index. php/anais/article/view/2041/1999.

34. Soares RR. The effect of longevity on schooling and fertility: evidence from the Brazilian Demographic and Health Survey. J Popul Econ 2006; 19:71-97. 
35. Soares RR. Mortality reductions, educational attainment, and fertility choice. Am Econ Rev 2005; 95:580-601.

36. Hagestad GO, Call VRA. Pathways to childlessness: a life course perspective. J Fam Issues 2007; 28:1338-61.

37. Tanturri M, Mencarini L. Childless or childfree? Paths to voluntary childlessness in Italy. Popul Dev Rev 2008; 34:51-77.

38. Szalma I, Takács J. Who remains childless? Unrealised fertility plans in Hungary. Czech Sociol Rev 2015; 51:1047-75.

39. Hakim C. A new approach to explaining fertility patterns: preference theory. Popul Dev Rev 2003; 29:349-74.

40. Nahar P. The link between infertility and poverty: evidence from Bangladesh. Hum Fertil (Camb) 2012; 15:18-26.
41. Detels R, Gulliford M, Karim QA, Tan CC, editors. Oxford textbook of global public health. 6th Ed. Oxford: Oxford University Press; 2015.

42. Lanand M, Kuang Y. The impact of women's education, workforce experience, and the One Child Policy on fertility in China: a census study in Guangdong, China. Springerplus 2016; 5:1708.

43. van Balen F, Bos HMW. The social and cultural consequences of being childless in poorresource areas. Facts Views Vis Obgyn 2009; 1:106-21.

44. Rouchou B. Consequences of infertility in developing countries. Perspect Public Health 2013; 133:174-9. 


\section{Resumen}

La literatura reciente propone que la pobreza puede llevar a las mujeres a decidir no tener hijos, por lo que se atenúa o revierte la fertilidad, típicamente más alta, observada entre mujeres con formación educativa baja. Investigamos el papel de la salud en este planteamiento: ¿Tiene la salud un efecto distinto en la fertilidad entre mujeres con baja educación? Para tal fin, calculamos la brecha en la tasa de mujeres sin hijos según el estado de discapacidad autoinformado y nivel de educación. Debido a la escasez de datos sobre mujeres sin hijos en las encuestas, además del tamaño pequeño de las muestras, usamos muestras del censo. Centrándonos en mujeres con un intervalo de edad entre 40 y 50 años, y usando 23 muestras de censos de países latinoamericanos (2000-2011), hallamos que solo en el grupo con baja educación hay una clara brecha en la tasa de mujeres sin hijos según estado de discapacidad autoinformado. Desde nuestro análisis descriptivo concluimos que la salud puede jugar de hecho un papel influyente en la ausencia de hijos por el enfoque de pobreza.

Fertilidad; Educación; Pobreza

\section{Resumo}

A literatura recente sugere que a pobreza pode fazer com que as mulheres permaneçam sem filhos, assim atenuando ou revertendo as taxas de fertilidade mais elevadas observadas tipicamente em mulheres com baixa escolaridade. O estudo investiga o papel da saúde nessa abordagem: A saúde tem efeito negativo discernivel na fertilidade de mulheres com baixa escolaridade? Para responder a essa pergunta, calculamos a diferença na taxa de ausência definitiva de filhos de acordo com a infertilidade autorrelatada, entre diferentes níveis de escolaridade. Devido à escassez de dados sobre mulheres definitivamente sem filhos, além das amostras pequenas, utilizamos amostras censitárias. Com foco nas mulheres na faixa etária entre 40 e 50 anos, e utilizando 23 amostras censitárias de países latino-americanos (2000-2011), detectamos que apenas no grupo de baixa escolaridade, há uma defasagem clara na taxa de ausência definitiva de filhos de acordo com a infertilidade autorrelatada. Com base em nossa análise descritiva, concluímos que a saúde pode desempenhar um papel importante na análise da ausência de filhos em mulheres pobres.

Fertilidade; Educação; Pobreza
Submitted on 31/Dec/2019

Final version resubmitted on 18/May/2020

Approved on 22/May/2020 